\title{
Why Have the Scientists Accepted The Illogical Proposal of Zuckerman for 60 Years?
}

\section{Othman Salim Hussein AI-Fleesy*}

Department of Forensic Medicine and Pathology, Faculty of Medicine and Health Sciences, Aden University, South Yemen

\section{Introduction}

\section{The origin of the problem}

Since Zuckerman proposal in 1951, in which he reported that females have a fixed number of oocytes in her foetal life and stop producing oocytes after birth [1]. This long-standing (dogma) by Zuckerman had arrested a created think and losing decades of research for 60 years, based on this misleading finding and wrong proposal. So, the direction in studying this matter in embryology was absent because the most of the scientists had accepted this supposition.

\section{The recent opinions}

Currently, Johnson et al. [1] criticized that old dogma of nonproduction of oocytes after birth.

He suggested that stem cells were found in embryo and certain adult body tissues having the potential to grow into different types of cell. $\mathrm{He}$ wrote: (stem cells go right into your blood supply and go right to your ovaries resulting in production of new oocytes) [2]. This assumption led to another hot debate. David Albertini calls such claim outrageous and a frank travesty that has falsely raised the hopes of many women.

Woods et al. noted that there are still no evidence that the oogonia stem cells form new eggs naturally in the body and other criticized this assumption too [3].

\section{What is written about oogenesis?}

The embryological textbooks (based on old doctrine) had mentioned that the females in their foetal life having about two million of primary oocytes in their ovaries [4]. Most regress during their childhood so that by adolescence only about 40,000 cells remain, of these only approximately 400 become secondary oocytes and are expelled at ovulation during reproductive period [4].

\section{Opinion and comments of the author}

Fortunately, Zuckerman had admitted that he had forwarded his supposition without any experiment; this gives us the right to criticize and speculate his old supposition. Previous studies have reported a number of results most of them are with the Zuckerman's proposal and a few were against it.

Why is there a controversy about stem cell producing oocytes (Tilly) and about non-production of oocytes after birth (Zuckerman)?

The author thinks that the strongest evidences indicating that the previous proposals were unsuccessful, unconvincing, and illogical are:

1. It was illogical supposition (belief) of Zuckerman that there is no oocytes production after birth because this interpretation against dynamic of life and development of human being. The growth and division of cells are the main features of all organisms including humans. The continuing production of new oocytes is one these human features.

The author asks the biologists: how could cells (oocytes) be created, divided, and developed at the beginning of foetal life and stop division or production suddenly at the seventh month of foetal life and continuing this stoppage after birth while every cell in the body is continuing division, growth in the race of development?

So, if this proposal of Zuckerman is true (which is not so) Logically the age of primary oocytes and in-depth - after birth - must be the same and static as in foetal life (not more than 7 months) because there is no production after birth and they stay dormant and latent as biologists stated in their textbooks.

how can these primary oocytes remain dormant-after birth- for years of life with the same static age ( 7 months), and then they may wake up after more than ten years, and a number of them (group) (12-1000 primary oocytes) begin the process of division and one only ovulated, while others (40000--700000) still dormant [5,6].

2. Illogical total number of oocytes and a big mistake in estimating and calculating these oocytes. Some embryologists wrote one million and others said it reached seven million. This huge, wrong number leading to mistrusted results.

3. Unsuccessful explanation of embryologists for the primary oocytes division at puberty period and the beginning of monthly ovarian cycle. They stated that after birth and at puberty the Primary oocytes after their dormant and suspended prophase they completed their division and before ovulation (36-48) hours the secondary oocytes enter to metaphase stage and arrested to be completed after fertilization. And they had related this long dormant to occurrence of chromosome 21 disorder (Trisomy 21) and Down syndrome.

How could we say that at puberty the ovum matured and ovulates, but we did not remember what happened during these years (infancy - puberty)? Because these ova are not growing and maturing suddenly, but they have entered the process of development and growth since fertilization (with all stages) till maturity.

The process of mitosis continues until we were born, and continues until we were grown up. No one knows when cells stop growing. Nobody knows exactly how much you will grow. And what causes the human body to grow.

4. Growth is a fundamental characteristic of humans. It is Unequivocal that cells have programmed by the creator (The God), and the growth is going in different stages (phases), from zygote, Neonate, infant, up to full maturity. Every stage (period) has its own requirements and time (age).

*Corresponding author: Othman Salim Hussein Al-Fleesy, Department of Forensic Medicine and Pathology, Faculty of Medicine and Health Sciences, Aden University, Aden, South Yemen, Tel: +967 739236 414; E-mail: alfleesy2001@yahoo.com

Received January 27, 2017; Accepted February 06, 2017; Published February 08 2017

Citation: Al-Fleesy OSH (2017) Why Have the Scientists Accepted The Illogical Proposal of Zuckerman for 60 Years? J Mol Biomark Diagn 8: 331. doi: 10.4172/2155-9929.1000331

Copyright: ( 2017 Al-Fleesy OSH. This is an open-access article distributed under the terms of the Creative Commons Attribution License, which permits unrestricted use, distribution, and reproduction in any medium, provided the original author and source are credited. 
Citation: Al-Fleesy OSH (2017) Why Have the Scientists Accepted The Illogical Proposal of Zuckerman for 60 Years? J Mol Biomark Diagn 8: 331. doi: $10.4172 / 2155-9929.1000331$

Page 2 of 2

Overbeck defined time as: The Great gift of nature which prevents the occurrence of everything at once. But in fact the time is the gift of the creator the GOD. Also, (an arrow of time) is a term released by a famous British physician in 1928, he stated: time has one direction [5]. All living humankind is the result of the movement of time which is estimated by time scaling (hours, days, months, and years). Nothing happens outside time except the God miracle of cavemen. Allah says: (So we cast (a cover of sleep) over their ears within the cave for a number of years [6]. And Allah says: And they remained in their cave for three hundred years and exceeded by nine [7]. Everything on the earth's surface has a time's brand (obvious or hidden).

5. Again, It is clear that there is a jump on the time (period, age), when the scientists stated that the oocytes after birth remain in dormant or suspended status till the puberty or menopausal age. How could these cells be out of time with no growth?

In human body, the growth includes all the organs, tissues, and cells. Please look to these samples and examples of growth whatever the function of organ is:

a. The thymus glands start development in infancy and childhood. After puberty, it starts to slowly shrink and become replaced by fat.

b. The growth of the bone (faster), starting by ossification centres (foetal life and to ending in full maturity).

c. The growth of the teeth starting with milk teeth in infancy and ending with the last one wisdom teeth (third molar) of the permanent teeth.

d. The disappearance of RBCs nuclei after their maturity.

The growth and division of cells are important of almost all organism including humans. Naturally Ovaries are continually producing new eggs as the organ has this ability to producing. Who is able (from scientists) to prove that there is no division, no growth, and no production after birth.

It was a false claim by Tilly and others when they concluded that stem cells are coming from bone marrow or peripheral blood to locate in this site (ovary) and to produce new oocytes or to replenish or to generate them which raised a controversial more than Zuckerman proposal.

Stem cells that come from bone marrow or blood (if this is true and proved because scientists still in doubt), may have other tasks or missions in the body elsewhere still not discovered by biologists, but not to generate or produce oocytes, because oocytes have another wellequipped factory (the ovary).

\section{Conclusions}

After reviewing these proposals, the author concluded:

1. There is a continual production of new oocytes till the decline of normal physiology of the human female body. The continual production of oocytes is still of unknown origin to researchers but definitely there is programmed self-creating and production of these new egg cells from ovaries - but not stem cells - never mentioned before [8].

2. The human body has an integral and complex physiology, so the previous false proposal (non-production of oocytes after birth), reflected itself in studies and results of scientists and their misinterpretation in giving terms and words which did not represent the main concept such as: dormant primary oocytes, suspended prophase, atretic oocytes in foetal ovaries.... etc.

3. The egg cells (oocytes) created and produced in their ovaries, it is the only factory for this production. The factory of airplanes never produced cars.

4. Inability to (observing) the continuity of creation and growth of new egg cells by either due to our lack of knowledge or deficiency in technology : the available tools, devices, equipment's etc., does not consider an evidence against the presence and production of egg cells in ovaries. Because it may be a secret and mystery of God Allah says: $I$ did not make them witness to the creation of the heavens and the earth or to the creation of themselves, and I would not have taken the misguiders as assistants [9].

5. The scientists must -whatever their science and knowledge they have- remember always that the human being is created by the creator who gave you this science, and life and to remember too that the universe including the humans is controlled by the God, so if you do not believe this, please push, and stop death by your science and technology. Allah says: They ask thee concerning the Spirit (of inspiration) Say: "The Spirit (cometh) by command of my Lord: of knowledge, it is only a little that is communicated to you $[8,9]$.

6. Finally, on the basis of previous comments, the author calls all scientists in this field to revise again the process of spermatogenesis.

\section{References}

1. Zuckerman S (1951) The number of oocytes in the mature ovary. Rec Prog Horm Res 6: 63-109.

2. Johnson J, Canning J, Kaneko T, Pru JK, Tilly JL (2004) Germline stem cells and follicular renewal in the postnatal mammalian ovary. Nature 428: 145-150.

3. Woods DC, Telfer EE, Tilly JL (2012) Oocyte family trees: Old branches or new stems? PLOS Genet 8: e1002848.

4. Sadler TW (2015) Langman's Medical Embryology, (13thedn).

5. Zawail A (2007) Time's mysteries and miracles- Consonance with physical and life sciences, Bibliotheca Alexandrina, Egypt.

6. Holy Qur'an, Surah: Al-kahf (The Cave) verse 11.

7. Holy Qur'an, Surah: Al-kahf (The Cave) verse 25.

8. Holy Qur'an, Surah: Al- Israa Verse 85.

9. Holy Qur'an, Surah: Al-kahf (The Cave) verse 51. 